\title{
Selection of Resistance to Venturia inaequalis in Apple: Using Phenotypic and Genotypic Methods in Combination
}

\author{
Rameez Nazir Rather ${ }^{1 *}$, Zahid Hussain Najar ${ }^{1}$, Aijaz A. Wani ${ }^{1}$, Mehraj-ul-din Shah ${ }^{2}$ \\ ${ }^{1}$ Department of Botany, University of Kashmir, India \\ ${ }^{2}$ Division of Plant Pathology, Sher-e-Kashmir University of Agricultural Sciences and Technology of Jammu, India
}

Submission: February 13, 2018; Published: March 28, 2018

*Corresponding author: Rameez Nazir Rather, Cytogenetics and Reproductive Biology Laboratory, Department of Botany, University of Kashmir, Srinagar - 190006 India, Email: rameez674@gmail.com

\begin{abstract}
Apple is a very important fruit crop grown mostly in temperate parts of the world. Millions of people are associated with apple trade. Every year huge economic losses are caused by many diseases of which apple scab caused by fungus Venturia inaequalis is the deadliest one. Fungicide sprays along with disease forecasters are used in the management of the disease with limited success. Planting scab resistant cultivars is the best strategy as it is eco-friendly and cost effective. For identifying scab resistant genotypes, to be used directly as cultivars or using them in breeding programs to develop scab resistant cultivars, phenotypic methods as well as genotypic methods are used. We discuss each method and propose that both the types of screening methods should be used in combination to get more reliable results.
\end{abstract}

Keywords: Venturia inaequalis; Apple scab; Resistance breeding; Molecular markers

\section{Introduction}

Apple (Malus $\times$ domestica Borkh.) is an important fruit species widely cultivated in the temperate regions of the world [1]. It ranks third in terms of production with annual production of about 84.6 million tons [2]. Apple is a major industry and millions of people are associated with it. However like any other crop species many diseases cause huge economic losses to the growers. Apple scab caused by the fungal pathogen Venturia inaequalis is the major disease of apples in almost all parts of the world where it is cultivated. Strategies like disease predictors or forecasters combined with fungicides have been employed in scab management with some degree of success $[3,4]$. Fungicide use is unpleasant as it is costly besides being hazardous ecologically. The fungicides also tend to get accumulated in the fruit thus making fungicide treated apples unpopular among the consumers. The best option is the development of blemish free fruit devoid of any pesticide residues. To find such cultivars one has to identify scab resistant varieties from all the genotypes of a region [5]. Majority of scab resistant apple varieties are of inferior quality than Venturia inaequalis susceptible but high quality apples. In such cases the scab resistant varieties are used in breeding programs with other varieties of high quality to develop good quality scab resistant apples [6]. The paper presents different methods used for identification of scab resistant sources in apple and discuses how a combination of phenotypic and genotypic screening methods is more reliable than using only one method of the two.

\section{Different Resistance Identification Methods}

Screening scab resistant genotypes is carried out at phenotypic as well as genotypic levels. Pheno typing for scab resistance is carried out through various methods. The easiest of all is the field evaluation. An orchard is chosen and visited many times during a year to record severity of disease symptoms on all the genotypes. No fungicides are used throughout the study period to avoid wrong assessment of resistance [7]. Another phenol typing method is through the artificial inoculation of potted genotypes under glasshouse conditions. Firstly a spore suspension of Venturia inaequalis is prepared [8]. The conditions inside the glasshouse are set to encourage the development of 
the pathogen (temperature $20{ }^{\circ} \mathrm{C}$ and relative humidity 85\%). 2 to 3 weeks post-inoculation the potted plants are classified according to the grading system with $0-4$ class scale: genotypes with class 0, 1, 2 and 3a are graded as resistant and trees showing class $3 \mathrm{~b}$ and 4 symptoms are graded as susceptible [9]. Screening through potted trees requires lot of resources and time as it is very demanding to maintain a huge population under glasshouse conditions. A simple and easier method is the detached leaf method. Detached leaves from all the genotypes are collected at young stage and are inoculated with the spore suspension of Venturia inaequalis in Petri plates containing water agar or wet whatman filter to maintain high relative humidity required for the growth of the pathogen. The Petri plates are then incubated for 3 to 5 weeks at 20 to $25{ }^{\circ} \mathrm{C}$. Leaves are then assessed for symptoms and it has been shown that susceptible genotypes show chlorosis 3 weeks after inoculation and become necrotic after 5 weeks [10]. Although this method is simple and a large number of genotypes can be screened through this method, however, accuracy of the method is poor as leaves of different ages from the genotypes can give erroneous results due to different ontogenic resistance levels owing to age differences between the leaves the age difference arises because all the trees do not bear leaves at the same time.

About 20 major scab resistance genes have been identified in different apple genotypes [11]. For screening at the genotypic level DNA is extracted from all the genotypes and genotyping is carried out through markers linked to the scab resistance genes. The exact method of genotyping depends upon the type of marker (like SSR, SNP, RAPD, SCAR) used in the essay. Of all the marker types SSR are preferred due to various advantages over other marker systems. They have high reproducibility and thus results do not differ between two laboratories. They are also easy to analyze and interpret. However the initial cost of development requires a lot of effort and resources. But this is not any problem with markers linked to apple scab resistance genes as markers for most of the genes have already been developed.

\section{Genotypic and Phenotypic Screening Methods Should Be Used In Combination}

Selection of resistance through only one of the methods described above can give inaccurate results. Whenever screening tests are carried out for selection of scab resistance, a combination of phenotyping and genotyping should be carried out. Screening through any of the Phenotyping methods can give false results. Field evaluation is never reliable if done without genotyping. This is because sometimes the pathogen does not reach all the plants in an orchard. This phenomenon is called as disease escape. In such a situation one can easily classify a susceptible genotype as scab resistant. Inoculation methods described above if carried out without marker analysis can also give misleading results. A type of resistance called ontogenic resistance increases with increasing age of the leaves. As Leaf emergence on potted plants does not occur simultaneously, there is always age difference between the leaves of different genotypes. The leaves of plants with older leaves will be more resistant than those plants that have relatively young leaves. The same flaws are also present in screening through detached leaf method. As far as resistance selection through molecular markers is concerned, it is very clear that environmental effects do not come into play. However the problem arises if a marker is located far from the actual gene. The marker and gene might segregate during meiosis and get separated. Upon genotyping we can detect the marker and if the marker is far off from the actual gene, we may wrongly interpret the presence of the gene when in fact only marker is present in the genotype.

\section{Conclusion}

It is clear that all the methods described above can give erroneous results if used alone. So the best way for identifying scab resistance is by using both genotypic as well as phenotypic methods. For example if we wrongly interpret a plant as resistant during field assessment, molecular markers can come to our rescue and show that the plant is not scab resistant. Similarly if we classify a genotype as resistant through inoculation methods when in fact the resistance is due to leaf age or quantitative resistance, molecular markers might classify them as susceptible. Lastly if we wrongly interpret the presence of a resistance gene through molecular markers (when in fact only marker is present) inoculation method will classify that as susceptible. Thus we suggest that for screening scab resistance sources a combination of phenotypic and genotypic methods should be carried out to get authentic results.

\section{References}

1. Harris SA, Robinson JP, Juniper BE (2002) Genetic clues to the origin of the apple. Trends in Genetics 18(8): 426-430.

\section{FAOSTAT (2014) FAO statistics division.}

3. Fisher PD, Lillevik SL (1977) Monitoring system optimizes apple tree spray cycle. Electronics 50: 125-127.

4. Ellis MA, Madden LV, Wilson LL (1984) Evaluation of an electronic apple scab predictor for scheduling fungicides with curativea activity. Plant disease.

5. Dar MS, Mohammed I, Sofi TA, Hanger FA, Shah MD, et al. (2015) Distribution of Apple Scab Race Flora and Identification of Resistant Sources against Venturia inaequalis in Kashmir. Plant Pathology Journal 14(4): 196-201.

6. Gessler C, Patocchi A, Sansavini S, Tartarini S, Gianfranceschi L (2006) Venturia inaequalis Resistance in Apple. Critical Reviews in Plant Sciences 25(6): 473-503.

7. Lateur M, Populer C (1994) Screening fruit tree genetic resources in Belgium for disease resistance and other desirable characters. Euphytica 77(1-2): 147-153.

8. Barbara DJ, Roberts AL, Xu XM (2008) Virulence characteristics of apple scab (Venturia inaequalis) isolates from monoculture and mixed orchards. Plant Pathology 57: 552-561.

9. Chevalier M, Lespinasse Y, Renaudin S (1991) A microscopic study of the different classes of symptoms coded by the Vf gene in apple for resistance to scab (Venturia inaequalis). Plant Pathology 40: 249-256. 
10. Yepes LM, Aldwinckle HS (1993) Selection of resistance to Venturia inaequalis using detached leaves from in vitro-grown apple shoots. Plant science 93 (1-2): 211-216.
11. Khajuria YP, Kaul S, Wani AA, Dhar MK (2018) Genetics of resistance in apple against Venturia inaequalis (Wint.) Cke. Tree Genetics \& Genomes 14(16).

\section{Your next submission with Juniper Publishers will reach you the below assets}

- Quality Editorial service

- Swift Peer Review

- Reprints availability

- E-prints Service

- Manuscript Podcast for convenient understanding

- Global attainment for your research

- Manuscript accessibility in different formats

( Pdf, E-pub, Full Text, Audio)

- Unceasing customer service

Track the below URL for one-step submission https://juniperpublishers.com/online-submission.php 